\title{
Understanding Business Relationship Management in China: A Power and Leverage Perspective
}

\author{
Daniel Chicksand \\ Aston Business School, Birmingham, UK \\ Jakob Rehme, Daniel Nordigarden \\ Linköping University, Linköping, Sweden \\ Tong Yang \\ Unilever, Leatherhead, UK
}

\begin{abstract}
This paper examines whether a power and leverage perspective, successfully applied to analyse extended buyer-supplier relationships in a western context, can be used to analyse business relationships in China. A single embedded case study is presented in this paper and a power and leverage approach is used to analyse business relationships. The power and leverage perspective is applicable for investigating buyer-supplier relationships in a Chinese cultural context. However, in this context using power as coercion is an extremely counterproductive relationship management strategy, which can draw both buyers and suppliers in to a "no-win" or negative sum situation. The findings are based upon a single case, which makes drawing generalisable conclusions more difficult. In addition, although every effort was made to limit the subjectivity of the power and relationship analysis, researcher interpretation of the data was required. In the Chinese business context, it may not be advisable to manage any relationships in an arms-length manner. Chinese business networks are centred on less explicit or formal power relationships and therefore companies that have learnt the rules of the game of exchange in the west need to modify their approach in China. This work extends the understanding of buyer-supplier relationships and provides additional empirical evidence validating a power and leverage perspective. In addition, the paper provides the first assessment of whether this approach can be used in a non-western context without significant modification.
\end{abstract}

Keywords: buyer-supplier relationships, power, culture, China

\section{Introduction}

Business-to-business relationship management is a key area of interest for managers and academics, like Ulaga and Eggert (2006), Su, Song, Li, and Dang (2008), and Meehan and Wright (2011). It has long been argued that the effective management of buyer-supplier relationships can lead to competitive advantage (Spekman, 1988; Dyer \& Singh, 1998; Dyer, 1996; Zaheer, McEvily, \& Perrone, 1998; Jap, 1999; Kim, S. H.

Daniel Chicksand, Ph.D., senior lecturer, Aston Business School, Aston University, Birmingham, UK.

Daniel Nordigården, Ph.D., associate professor, Department of Management and Engineering, Linköping University, Linköping, Sweden.

Jakob Rehme, Ph.D., associate professor, Department of Management and Engineering, LinköpingUniversity, Linköping, Sweden. Tong Yang, MBA, Unilever’s Corporate Supply Chain Strategy Team, Unilever House, Springfield Drive, Leatherhead, UK. Correspondence concerning this article should be addressed to Daniel Chicksand, Operations and Information Management Group, ABS 265, Aston Business School, Aston University, Birmingham, B47ET, UK. E-mail: d.chicksand@aston.ac.uk. 
Park, Ryoo, \& S. K. Park, 2010; Emberson \& Storey, 2006). In today’s global market, network and relationship building are seen to be critical for success and the survival of businesses (Park \& Luo, 2001). In the context of today's global economy, understanding how cultural differences can impact business relationships has become an increasingly important focus (Ribbink \& Grim, 2010; Hofstede, 1980; House, Javidan, \& Dorfman, 2001).

Prior research into buyer-supplier relationships has used a number of theoretical perspectives to help understand the phenomenon, for example, agency theory (Eisenhardt, 1989; Himmelweit, Simonetti, \& Trigg, 2001) and transaction cost economics (TCE) (Williamson, 1975, 1985, 1995) have been the theoretical engines for numerous empirical studies. Resource dependence theory (RDT), as made popular by Pfeffer and Salancik (1978), has been employed in multi-disciplinary research focusing on explaining how organization can reduce environmental interdependence and uncertainty (Hillman, Withers, \& Collins, 2009, p. 1404). Building on RDT, Cox, Sanderson, and Watson (2000) developed a power and leverage perspective for exploring the commercial outcomes of buyer-supplier relationships. However, their research has only been conducted in a western context.

To address this, the authors conduct an empirical study in a Chinese business context and analyse buyer-supplier relationships using a power and leverage perspective (Cox et al., 2000). This leads to the key research question: Does the power and leverage perspective need modifying in non-western contexts?

To explore this research question, this paper will firstly discuss the concept of power in buyer-supplier relationships. Secondly, a power and leverage perspective (Cox et al., 2000) will be discussed. Thirdly, authors will explore the impact that the Chinese cultural context can have on business relationships. Finally, authors will operationalize a power and leverage perspective (Cox et al., 2000) and use it to analyse the relationships between a number of buyers and suppliers in a Chinese multiple food market context.

This paper makes a number of important contributions to the understanding of buyer-supplier relationships. Firstly, through the presentation of an in-depth case, the paper delivers important empirical guidance for those who intent on measuring buyer-supplier power relationships. The methodology presented aims to shed light on how, in practice, one can determine who has power in a relationship. Secondly, empirical evidence is provided which explores the boundary conditions of a power and leverage perspective (Cox et al., 2000). Finally, potential refinements will be suggested to this perspective for analysing business relationships in a Chinese cultural context.

\section{Understanding Power}

Power is multi-dimensional (Ireland, Webb, \& Coombs, 2005) and "an essentially contested concept" (Gallie, 1955), in that many disagree as to how exactly the concept should be understood and what its scope should be. Some scholars argue that there are much more subtle expressions of power and that power is not always displayed in overt and observable acts (Bachrach \& Baratz, 1962). Indeed, some have exploited this contestation to actually deny the importance of the concept (Williamson, 1995). There is however, a considerable body of literature that focuses on power. A number of authors consider the role of power within organizations, for example, Contu and Willmott (2003) talked about the embeddedness of learning practice in power relations. They argued that learning practices are shaped, enabled, and embedded within relations of power, whereby power is determined by "the social organization of and control of resources" (Lave \& Wenger, 1991). Fleming and Spicer (2006), also focusing on power within organizations, stressed that there are four distinct "faces" to power where each face has distinct answers to what power is, how it operates, and how it is maintained in organizations. These results in the study of power are multi-faceted and complex. In addition, 
French and Raven (1959), working in the field of sociology, identified five sources of power: reward, coercive, legitimate, expert, and referent. They emphasized that although actors may have potential power, they often chose not to exert it fully. The difficulty in understanding and defining power is a possible reason why many scholars have chosen to use alternative theories to help explain phenomenon such as buyer-supplier relationships. Authors would argue, as Pfeffer and Salancik (1978) do, that although it may be difficult to define power, the consequences of power can be observed all around. Those who have power achieve their desired outcome, whilst those who do not rarely achieve them. This paper explores the power dynamics among organizations rather than individual actor's within an organization. The working definition of power employed in this paper, in the context of understanding buyer-supplier relationships, as developed by Lukes (1974), is the ability of one actor to affect the behavior of another actor in a manner contrary to the second actor's interest. This definition is similar to those of Dahl (1957), Emerson (1962), and Bowles and Gintis (1993), amongst others. In this paper, the actors are buying and selling organizations and therefore power relationships rather than power in itself will be considered (Foucault, 1982).

\section{Power and Leverage Perspective}

Cox et al.'s power and leverage perspective (2000) builds upon the work of Emerson (1962) and other author's work (Blau, 1964; Thompson, 1967; Jacobs, 1974; Cook, 1977; Cook \& Emerson, 1978; Campbell \& Cunningham, 1983; Porter 1979, 1980). Cox (2007) argued that the dominant approach to understanding power relationships is seen as a function of resource dependency (or asymmetrical interdependence) (see also Caniëls \& Gelderman, 2005; Meehan \& Wright, 2011). From this perspective, it is therefore possible, by considering the degree of resource dependency, to determine the relative power of a buyer over a supplier. However, to do so, it is necessary to fully appreciate the buyer-supplier relationship context. This requires building up an understanding of the relationship from both the buying and supplying organizations standpoints. In this way, the power and leverage perspective fully acknowledges that power is, as Fleming and Spicer argued (2006), causal, episodic, and situational. This recognition is an important departure from earlier studies which have tended to focus on the effects of dependence upon only the buyer (e.g. El-Ansary \& Stern, 1972; Kim et al., 2010).

The power and leverage perspective, grounded in RDT, uses the constructs of resource utility, resource scarcity, and information scarcity. This paper will introduce how the perspective has been constructed, as this will enable any potential limitations of their models to be explored when applied to the Chinese business context.

With the focus of study being the dyad, the starting point is to analyze the key attributes of power for both the buyer and the supplier. In line with Pfeffer's viewpoint (1981), this approach defines power as being relative. Therefore, from the analysis it is possible to situate a dyadic relationship in the "Power Matrix", as shown Figure 1. Power relationships will be located in one of four power positions: buyer dominance (>), interdependence (=), independence (0), and supplier dominance $(<)$ (Cox et al., 2000; Cox, Ireland, Lonsdale, Sanderson, \& Watson, 2002).

In the context of vertical business exchanges, there are structural power resources that enable a buyer or supplier to achieve their desired outcome. For buyers, these are the occurrence of "monopsony and oligopsony, low sunk and switching costs, regular market contestation, buying consortia and appropriate governance structure to eradicate ex ante and ex post opportunism in situations of incomplete contracting and bilateral dependency" (Cox, 2007). For suppliers, "superior endowments of capital, tangible and intangible assets, 
distinctive capabilities, intellectual property and know-how" (Cox, 2007) can provide them with significant power resources. According to Rumelt (1987), these are isolating mechanisms that help create imperfect markets. In addition, suppliers gain power from information asymmetry, as well as sunk and switching costs.

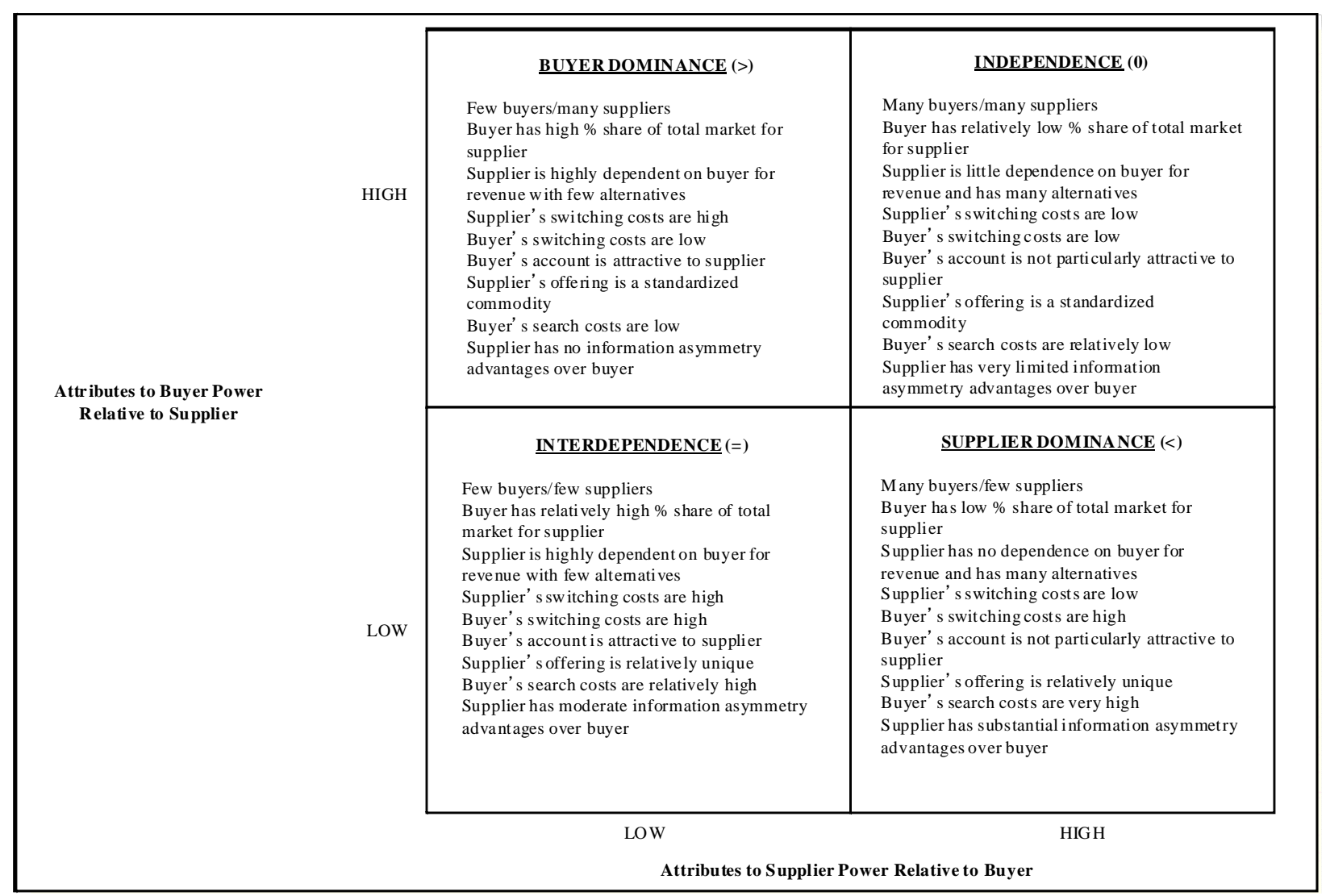

Figure 1. The power matrix. Source: Cox, Ireland, Lonsdale, and Sanderson (2003, p. 54).

\section{Relationship Management Choices}

Once the power relationship is analyzed, it is then possible to consider the full range of relationship management choices available for buyers and suppliers. There is little contestation, at least in a western focused academic context, that there is a range of inter-organizational relationship types. Authors can see the range of relationship types as a continuum from transactional to vertical integration (Spekman, Forbes III, Isabella, \& MacAvoy, 1998; Fontenot \& Wilson, 1997). Between these two extremes lie various hybrid governance forms (Figure 2).

There is, however, less agreement about the conditions under which different governance forms are more or less appropriate. Appropriateness of relationship choice is best understood by considering the reasons and the conditions under which organizations establish linkages or exchange with each other (Oliver, 1990). This could be the specific production process being employed (assembly line or batch) (Leenders \& Blenkhorn, 1988; Ramsay, 1996); the size of purchase (volume of business) (Spekman, 1988; Gadde \& Snehota, 2000) and the characteristics of the purchase (the level of complexity and criticality of the purchase) (Gadde \& Snehota, 2000). It can be argued, as many other authors do, that there cannot be one best way of working (Cannon \& Perrault, 1999). Therefore, there is arms-length or collaborative relationship management choices, both of which may be appropriate under particular operational conditions. Similarly, whenever commercial value is 
appropriated in a relationship, one party may achieve more than the other. In an unequal exchange, the subservient party has to accept the unequal terms of trade, although in some circumstances both may share the value relatively equally. Relationships can be described as being commercially adversarial or non-adversarial. Considering power and relationship management types together, six broad choices can be seen (Figure 3).

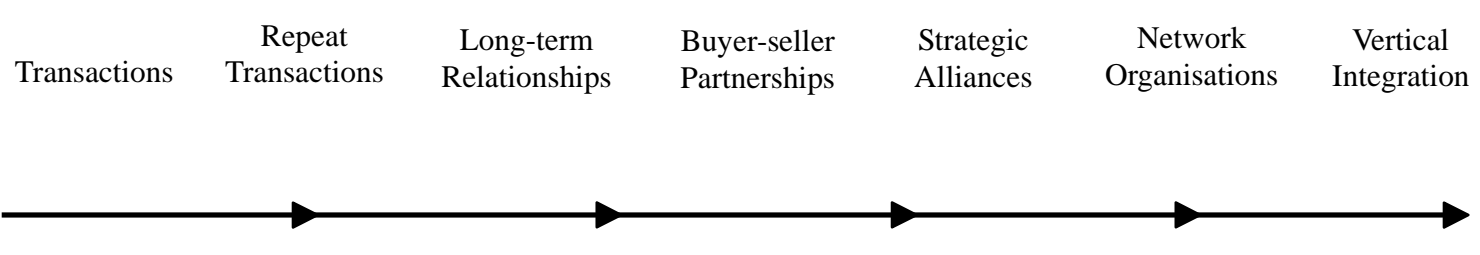

Figure 2. The range of marketing relationships. Source: Fontenot and Wilson (1997).

\begin{tabular}{|c|c|c|c|}
\hline \multirow{6}{*}{ 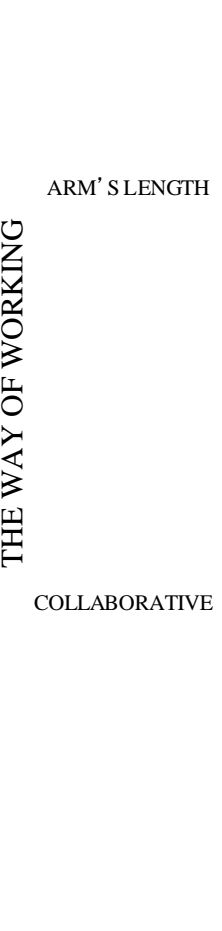 } & $\begin{array}{c}\text { BUYER DOMINANT } \\
\text { ARM 'S LENGTH RELATIONSHIP }\end{array}$ & $\begin{array}{l}\text { BUYER-SUPPLIER RECIPROCAL } \\
\text { ARM 'S LENGTH RELATIONSHIP }\end{array}$ & $\begin{array}{c}\text { SUPPLIER DOMINANT } \\
\text { ARM 'S LENGTH RELATIONSHIP }\end{array}$ \\
\hline & $\begin{array}{l}\text { Short-term operational relationship, with } \\
\text { limited close working between buyer and } \\
\text { supplier } \\
\text { Buyer adversarially appropriates most of } \\
\text { the commercial value created and sets price } \\
\text { and quality trade-offs } \\
\text { - } \quad \begin{array}{l}\text { Supplier is non-adversarial commercially } \\
\text { and a willing supplicant, accepting work }\end{array} \\
\text { rather than high margins/profitability from } \\
\text { the relationship } \\
\text { - Buyer Dominance power situation (>) }\end{array}$ & $\begin{array}{l}\text { Short-term operational relationship, with } \\
\text { limited close working between buyer and } \\
\text { supplier } \\
\text { Buyer accepts current market price and } \\
\text { quality trade-offs } \\
\text { - } \quad \begin{array}{l}\text { Supplier accepts normal (low) market } \\
\text { returns }\end{array} \\
\text { Both buyer and supplier operate } \\
\text { adversarially commercially whenever } \\
\text { possible, but normally have few leverage } \\
\text { opportunities } \\
\text { - Independence power situation (o) }\end{array}$ & $\begin{array}{l}\text { Short-term operational relationship, with } \\
\text { limited close working between buyer and } \\
\text { supplier } \\
\text { Supplier adversarially appropriates most of } \\
\text { the commercial value created and sets price } \\
\text { and quality trade-offs } \\
\text { Buyer is a non-adversarial commercially and } \\
\text { a willing supplicant, paying whatever is } \\
\text { required to receive given quality standards } \\
\text { Supplier Dominance power situation (<) }\end{array}$ \\
\hline & $\begin{array}{c}\text { BUYER DOMINANT } \\
\text { COLLABORATIVE RELATIONSHIP }\end{array}$ & $\begin{array}{l}\text { BUYER-SUPPLIER RECIPROCAL } \\
\text { COLLABORATIVE RELATIONSHIP }\end{array}$ & $\begin{array}{c}\text { SUPPLIER DOMINANT } \\
\text { COLLABORATIVE RELATIONSHIP }\end{array}$ \\
\hline & $\begin{array}{l}\text { - } \begin{array}{l}\text { Long-term operational relationship, with } \\
\text { extensive and close working between buyer }\end{array} \\
\text { and supplier } \\
\text { Buyer adversarially appropriates most of } \\
\text { the commercial value created and sets price } \\
\text { and quality trade-offs } \\
\text { - } \quad \begin{array}{l}\text { Supplier is a non-adversarial supplicant } \\
\text { commercially, and accepts work rather than }\end{array} \\
\text { high margins/ profitability from the } \\
\text { relationship } \\
\text { Buyer Dominance power situation (>) }\end{array}$ & $\begin{array}{l}\text { - } \\
\text { Long-term operational relationship, with } \\
\text { extensive and close working between buyer } \\
\text { and supplier } \\
\text { Buyer and supplier share relatively equally } \\
\text { the commercial value created } \\
\text { - } \quad \begin{array}{l}\text { Buyer and supplier agree price and quality } \\
\text { trade-offs, with supplier making more than }\end{array} \\
\text { normal returns } \\
\text { Both buyer and supplier operate non- } \\
\text { adversarially commercially } \\
\text { - } \quad \text { Interdependence power situation (=) }\end{array}$ & $\begin{array}{l}\text { - } \begin{array}{l}\text { Long-term operational relationship, with } \\
\text { extensive and close working between buyer } \\
\text { and supplier }\end{array} \\
\text { Supplier adversarially appropriates most of } \\
\text { the commercial value created and sets price } \\
\text { and quality trade-offs } \\
\text { - } \quad \begin{array}{l}\text { Buyer is a non-adversarial supplicant and } \\
\text { commercially, and pays whatever is }\end{array} \\
\text { required to receive given quality standards } \\
\text { Supplier Dominancepower situation }(<)\end{array}$ \\
\hline & \multirow[t]{2}{*}{$\begin{array}{l}\text { BUYER } \\
\text { DOMINANCE }\end{array}$} & $\begin{array}{l}\text { BUYER- } \\
\text { SUPPLIER } \\
\text { RECIPROCITY }\end{array}$ & \multirow[t]{2}{*}{$\begin{array}{l}\text { SUPPLIER } \\
\text { DOMINANCE }\end{array}$} \\
\hline & & PPROPRIATES VALUE FROM THE RELAT & \\
\hline
\end{tabular}

Figure 3. Relationship management choice matrix. Source: Cox, Lonsdale, Sanderson, and Watson (2004, p. 97).

From this perspective, therefore, there is "a causal relationship among the buyer-supplier power relationship, the type of interaction that is pursued and the commercial outcome of the relationship” (Lonsdale, 2004, p. 384). Although the unit of analysis is the dyad, from this perspective, it is possible to map extended power relationships through a chain. This is particularly important as often that effective relationship management choices are about understanding the dynamics at play in whole supply chains rather than at a dyadic level. Choi and Wu (2009, p. 7) argued that although the dyad may be the building block for analyzing networks they do not adequately "capture the essence of a network". It is better to consider extended buyer-supplier-supplier relationships what they term a triad. 
Having discussed power in buyer-supplier relationships and the power and leverage perspective, the next section of this paper will focus on buyer-supplier relationships in a Chinese cultural context.

\section{Relationships in a Chinese Cultural Context}

Many authors note that there are unique political, institutional, social, and cultural characteristics in China (Hofstede, 1980; G. Hofstede \& G. J. Hofstede, 2005; Humphreys, Shiu, \& Chan, 2001; Leung, Kock, \& Lu, 2002; Lee \& Oh, 2007; Cai, Yang, \& Hu, 2011). This gives rise to distinctive economic organization (Whitley, 1994; Boisot, 1986; Boisot \& Child, 1996), exchange structures (Keister, 2001), and present major supply-chain related problems or risks (Humphreys et al., 2001; Jiang, 2002; Cambra-Fierro \& Ruiz-Benitez, 2011). Furthermore, it is argued that the Chinese market is volatile, social culture is subtle, and the business environment and behavior are unique and sometimes incomprehensible ( $\mathrm{Li}, \mathrm{Lam}$, \& Qian, 2001; Graham \& Lam, 2003; K. Lieberthal \& G. Lieberthal, 2003; Vanhonacker, 2004; Chen \& Vishwanath, 2005).

It has been argued that success in the Chinese market stems from taking advantage of the opportunities presented by globalization, whilst being flexible enough to derive local solutions (Cambra-Fierro \& Ruiz-Benitez, 2011). As recent research has highlighted that, amongst other factors, strategic alliances with local partners provide opportunities for western organizations to adapt their practices to suit local culture (Cambra-Fierro \& Ruiz-Benitez, 2011; Salmi, 2006). Furthermore, when dealing with suppliers, retailers should be aware that “Guanxi relationships” drive business practice in the Chinese food retail market (Luo, 1997).

In China, all types of interpersonal connections are called Guanxi and can therefore be applied to dyadic business relationships (Yang, 1994; Xin \& Pearce, 1996). Guanxi literally means “a relationship” and stems from Confucianism.

The broad cultural aspects of collectivism are at the heart of Confucianism and influence all aspects of Chinese culture. This is particularly important for understanding how business relationships are formed and develop in the Chinese business context. Relationships in Chinese society are implicitly built upon "mutual interest and benefit” (Yang, 1994, pp. 1-2). According to Park and Luo (2001, p. 455), Guanxi has never been more relevant as this thinking is "entrenched in the present Chinese business environment".

It has been argued that for supply relationships in this market to flourish, they must be based upon trust and benefit both partners. In addition, it is paramount that in all dealings between retailers and their suppliers, face is maintained (Humphreys et al., 2001). Maintaining a certain level of "face" is very important in Chinese society and is a key dynamic within Guanxi. To establish and develop a Guanxi network, it is necessary to ensure that no loss of face occurs (Park \& Luo, 2001). Thereby, open request for cost information, for example, the overt use of power differentials (coercive power), prevalent in many buyer-supplier relationships in the west, would be interpreted in the Chinese context as a breakdown of trust in the relationship. This would result in individuals within an organization losing face (Humphreys et al., 2001).

Therefore the following proposition can be put forward:

P1: In a Chinese business context due to the influence of Guanxi and Mianzi (face), it is unlikely that power differentials in a relationship will be exploited.

\section{Research Methodology}

A power and leverage perspective is used to analyze extended buyer supplier relationships in a Chinese business context. As power is a complex and context-dependent phenomenon, determining power relationships 
requires research methods that can take into account situational and context specific factors (Mintzberg, 1983; Pettigrew, 1977; Pfeffer, 1981). Therefore, case-based research is appropriate as it provides a greater understanding of complex phenomenon (Voss, Tsikriktsis, \& Frohlich, 2002). Authors adopted a single embedded case research method of data collection (Yin, 1994), as it enables the researcher to gather rich information from the subjects through a variety of methods, including interviews, and document analysis (Yin, 2003). The case was introduced so as to illustrate and test the usability of the power and leverage perspective within a Chinese cultural context. By conducting the research in the context of a specific buyer-supplier interaction, the validity and reliability of the information were improved (Yin, 2003).

\section{Case Selection}

To address the research questions, authors sought a supply chain in China with a focal organization which was employing western management thinking/practices. A number of potential focal organizations were identified. It was crucial that the focal organisation would be able to facilitate access to their supply chain partners. Authors chose a single supply chain with four companies. The focus on an embedded case of single supply chain limits generalizability, but allows for greater depth and richness of study (Voss et al., 2002). The case studied was Westco and its roasted and raw seed and nuts supply chain described below.

Westco, the focal organisation, is a leading western multiple food retailer which has been highly successful in its native market. Their customer focus is to deliver low priced products and excellent service. Over the last 10 years, Westco expanded aggressively into a number of major developing markets in Asia and South America. With over 100,000 employees globally and more than 1000 stores, Westco commands significant purchase power.

Nutco, a small (less than 20 employees) local roasted nut business, was established in 1988. The business started as a nut shop and a number of investments were made to improve the processing methods, along with the development of a unique new recipe. This made Nutco's products distinctive in the marketplace. In 2000, Nutco commenced trading with a number of local food retailers and in 2004 signed an exclusive supply deal with Westco.

In addition to buying roasted seeds and nuts from Nutco, Westco also buys raw seeds and nuts from Rawco. Rawco is a small (less than 20 employees) local seeds and nuts supplier which purchases products from national wholesalers and sells in both local and regional markets. Finally, Nutco buys its raw seeds and nuts (to be further processed in their facility) from Seedco. Seedco is also a small (less than 20 employees) local seed and nut supplier.

\section{Data Collection}

Authors conducted in-depth face-to-face interviews with selected participants (senior management, marketing, operations, and procurement) in the buying and selling organizations. This paper used two semi-structured questionnaires designed to operationalize the power and leverage perspective. Face-to-face interviews were chosen rather than conducting a postal survey, as this allowed the researchers to gather richer data and to clarify, when necessary, complex questions.

Two semi-structured questionnaires were employed. The first was a "power and competition analysis questionnaire" (Tables 1, 2, and 3). The second was a "relationship management type questionnaire” (Table 4). The questions were drawn from a power and leverage perspective literature. They were then refined during a number of research meetings with colleagues knowledgeable in the field. Finally, the questionnaires were piloted with a number of buying and supplying organizations at a one-day workshop. 
Table 1

\section{Marketing Approach Questions}

1. What end product and/or service is the item under investigation being bought for?

2. For this end product, who are your key channel partners (\%) and what \% of total turnover (for the business) is attributed to each of these?

3. For a key customer, what do you supply?

4. What performance criteria are important to your key end customers?

5. What is your customer/competitive strategy as a supplier?

6. As a supplier, how do you manage your buyer? Do you see them as a development account, key account, low value account, or exploitation account?

Table 2

Buyer Power Resource Endowment Questions

\section{Interview Questions}

1. How operationally important is the item to be sourced? (U)

2. Is the item sourced of commercial importance? (U)

3. What \% of the total buyers spend is devoted to this item? (U)

4. Is reciprocity a factor in the relationship between the buyer and supplier? (U)

5. How many potential suppliers are there for this item of spend? (S)

6. How contested is the current supply market? (S)

7. How commoditised is the supply offering (level of complexity)? (S)

8. Are credible substitute items easily available? (S)

9. How high are the barriers to entry for new suppliers? (S)

10. How many isolating mechanisms does the supplier have against their competitors? (S)

11. Does the buyer pose a realistic threat of backward integration? (S)

12. Is it possible to take the first-tier supplier out of the chain? (S)

13. What is the current evidence of cartelisation in this supply market? (S)

14. What is the current level of lock-in by the supplier of the buyer's business? (S)

15. How high are the buyer's switching costs? (S)

16. Are the buyers search costs high or low? (I)

17. Does the buyer have low or high levels of information asymmetry? (I)

18. What type of product/service is being purchased (experience, search or credence)? (I)
Answers to provide maximum

level of power resource endowment for the buyer

Low

Low (support good)

Low

No

Many

High

Highly

Yes

Low

None or Few

High

High

Low

Low

Low

Low

Low

Search Good

Table 3

Supplier Power Resource Endowments Questions

\section{Interview Questions}

1. How significant is the buyer's spend to the operational sustainability of the supplier's business (i.e. ratio, regular and predictable)? (U)

2. How commercially important is the buyer to the supplier? (U)

3. Does the buyer provide supplier with clear and consistent demand forecasting and capacity planning information? (U)

4. Is the buyer's business attractive for the supplier? (U)

5. How many customers in total does the supplier have for this item? (S)

6. How many potential customers are there for this supplier? (S)

7. How high are the suppliers sunk costs? (S)

8. Does the supplier have the ability to forward integrate? (S)

9. Does the supplier have access to private buyer information (i.e. budgets, reservation price, what is valued, who specifies etc.)? (I)
Answers to provide maximum level of power resource endowment for the supplier

Low

Low

Yes

Low

Many

Many

Low

Yes

Yes 
Table 4

\section{Relationship Management Type Questionnaire}

\section{Section A: Defining way of working}

Q1: For the relationship in question, is there only a basic exchange of information and products or services, such as a basic specification, volume and timings information from the buyer and limited specification, timing and pricing information from the supplier?

Q2: Can evidence be provided demonstrating that the relationship has moved beyond an arm's length relationship? What specific product/process information exchange, operational linkages, legal bonds, cooperative norms and relationship specific adaptations are present in the relationship?

\section{Section B: Determining the sharing of surplus value in the relationship}

Q1: What are the commercial goals for the buyer and supplier (i.e. strategic ends, such as security of supply) of entering into this relationship?

Q2: Were these commercial goals fully or partially realised?

Q3: Is there an equal distribution of relationship specific investments?

Q4: If not, who has invested more in relationship specific adaptations (what evidence is there to support this)?

Q5: What profit margins does the supplier make?

Q6: What evidence is there in the contract (or agreement) to indicate an equal or unequal sharing of the surplus value (payment terms, length of contract, detrimental clauses, allocation of risks etc.)?

The power and leverage questionnaire was split into two sections (A and B), for logical data collection and subsequent analysis. Section A has six questions and focuses on determining the subject's marketing approach with customers (Figure 4 and Table 1). Section B was split into two sub-sections. B1 had 18 buyer-focused questions, aimed at determining buyer and supplier power (Figure 4 and Table 2). B2 had nine supplier focused questions, aimed at determining buyer and supplier power (Figure 4 and Table 3).

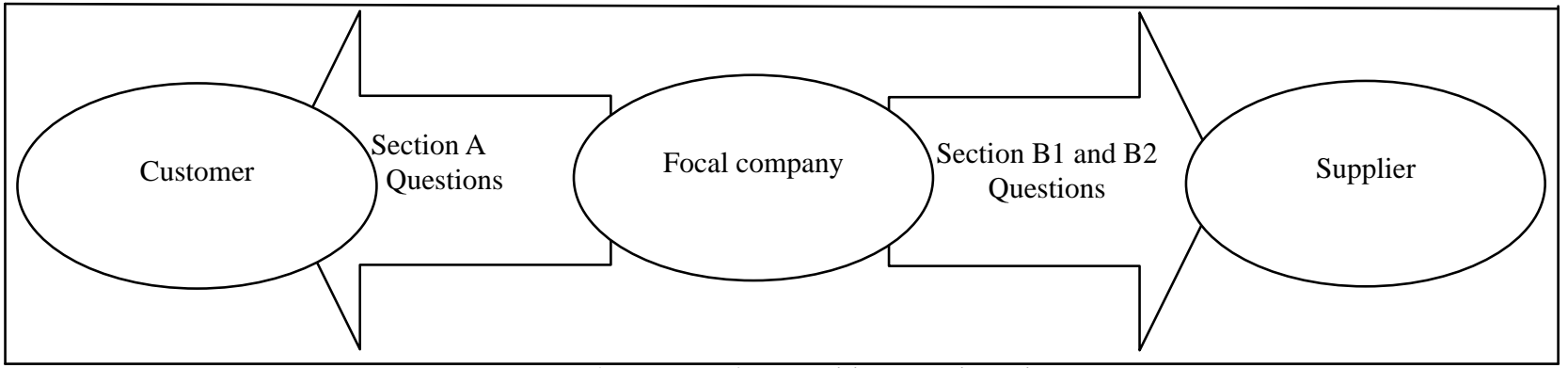

Figure 4. Power and competition questionnaire.

The questions shown in Tables 2 and $3^{1}$ were devised to determine:

(1) Relative utility (U) of the exchange: How important or valuable is this customer or supplier to the business?

(2) Scarcity (S): How many equivalent alternatives do people have beyond this customer or supplier?

(3) Information (I): How much do people know, or how easy/expensive would it be to find out the customer's reservation price or the supplier's cost of production?

The relationship management type questionnaire was also split into two sections. Section A had two questions which were aimed at determining the way of working between the two organizations (Table 4). Section B had a further six questions which were aimed at establishing the share of surplus value in the relationship.

\footnotetext{
${ }^{1}$ The second columns shown in Table 2 and 3 help data analysis. The process of data analysis is described in full in the next section of the paper.
} 
The data collection process is shown in Figure 5. Interviews were conducted in English and in Cantonese over an initial period of three months. The interviews took during two and three hours. The answers to the questions were transcribed and at a later date checked for accuracy with the interviewee. Safeguards were established to ensure that the data was robust. The process of data collection for the questionnaires ensured that the answers to the questions were validated by internal stakeholders and between the buying and selling organizations. Where possible, answers were also validated by external sources (industry reports etc.) and/or independent experts. The data came from a variety of sources ensuring adequate triangulation (Yin, 2003).

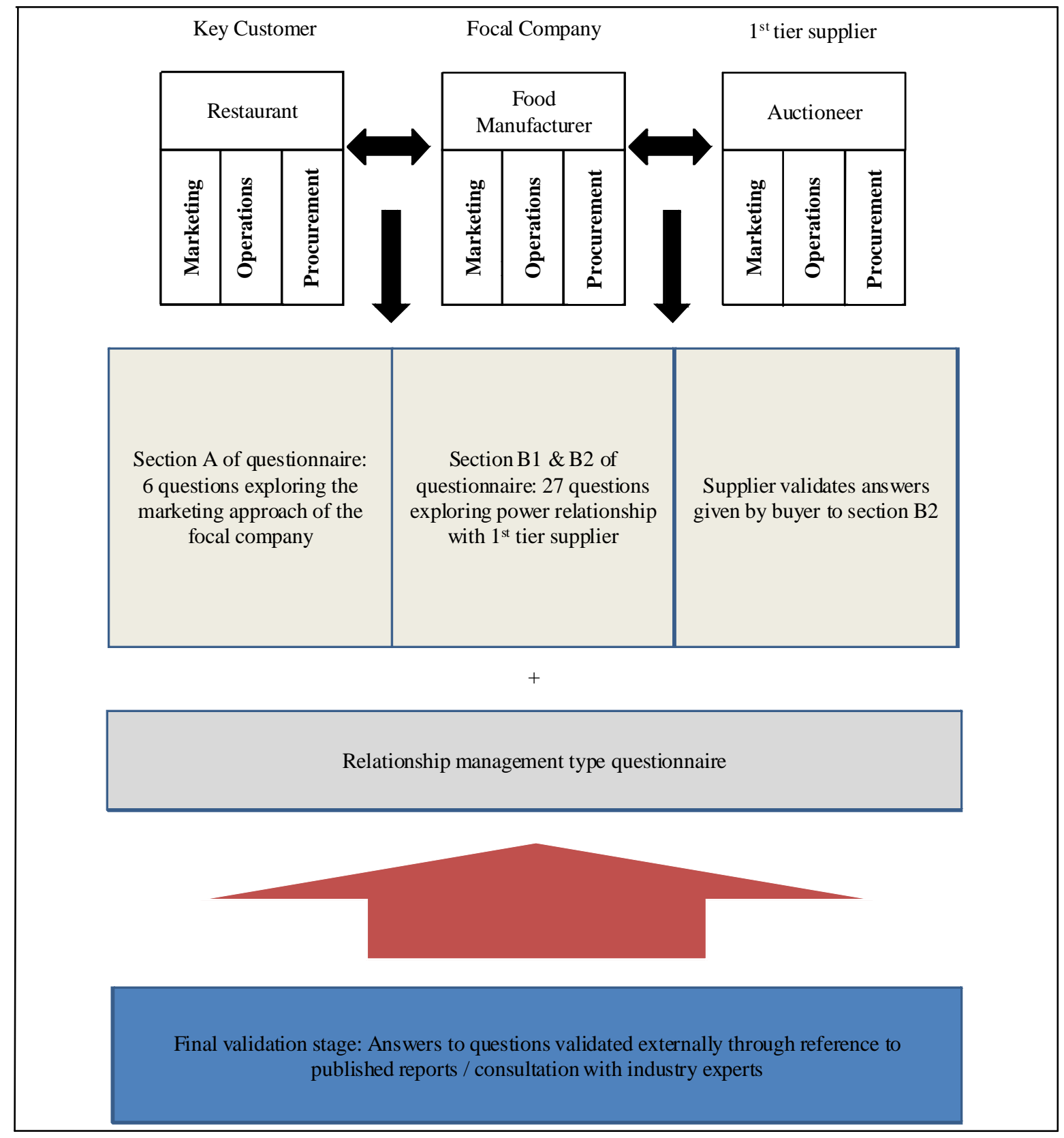

Figure 5. Data collection strategy and process. 
Table 5

Characteristics of Equal and Unequal Sharing of Surplus Value

\begin{tabular}{|l|l|l|}
\hline Buyer-skewed adversarial & Non-adversarial & Supplier-skewed adversarial \\
\hline Buyer's commercial goals fully achieved & $\begin{array}{l}\text { Each Party's commercial goals partially } \\
\text { realized }\end{array}$ & $\begin{array}{l}\text { Supplier's commercial goals fully } \\
\text { achieved }\end{array}$ \\
\hline $\begin{array}{l}\text { Supplier invested more in } \\
\text { relationship-specific adaptations }\end{array}$ & $\begin{array}{l}\text { Equal distribution of relationship specific } \\
\text { adaptations }\end{array}$ & $\begin{array}{l}\text { Buyer invested more in } \\
\text { relationship-specific adaptations }\end{array}$ \\
\hline $\begin{array}{l}\text { The buyer is paying a price which is } \\
\text { substantially lower than their utility } \\
\text { function (reservation price) }\end{array}$ & $\begin{array}{l}\text { The buyer is paying a price which is } \\
\text { mid-way between their utility function } \\
\text { (reservation price) and the supplier's mean } \\
\text { cost of production }\end{array}$ & $\begin{array}{l}\text { The buyer is paying a price very close to } \\
\text { their utility function (reservation price) }\end{array}$ \\
\hline $\begin{array}{l}\text { The supplier is receiving only normal } \\
\text { profit (or slightly above) }\end{array}$ & $\begin{array}{l}\text { The supplier is able to earn average profits } \\
\text { for the industry sector (comparable } \\
\text { companies operating at the same supply } \\
\text { chain stage) }\end{array}$ & $\begin{array}{l}\text { The supplier is able to earn sustained } \\
\text { above average profits for industry sector } \\
\text { (comparable companies operating at the } \\
\text { same supply chain stage) }\end{array}$ \\
\hline $\begin{array}{l}\text { The terms of the contract or agreement } \\
\text { favor the buyer (i.e. pricing, payment } \\
\text { terms, exit clauses, etc.) }\end{array}$ & $\begin{array}{l}\text { The terms of the contract or agreement } \\
\text { favor neither the buyer nor supplier (i.e. } \\
\text { pricing, payment terms, etc.) }\end{array}$ & $\begin{array}{l}\text { The terms of the contract or agreement } \\
\text { favor the supplier (i.e. pricing, payment } \\
\text { terms, exit clauses etc.) }\end{array}$ \\
\hline
\end{tabular}

\section{Data Analysis}

The first analysis step was to use the data to categorize each of the four relationships. Each relationship was categorized in one of the four power relationships shown in Figure 6. The process of analysis was as follows: A full power relationship analysis was conducted using the data collected from the survey (Table 1, 2, and 3); the second columns in Table 2 and 3 aid data analysis, for example, the first four questions shown in Table 2 determine the utility (U) of the purchase for the buyer. If the answer to question one is "low", then this will provide the buyer with high power resource endowments. Therefore, specific answers to each of the 18 questions shown in Table 2 demonstrate high power resource endowments for the buyer. The same logic is applied to the nine questions shown in Table 3 for determining supplier power resource endowments.

Bringing together the analysis of buyer and supplier, power resources enable to categorize the relationship in the box "power matrix". When the buyer has high attributes of power relative to the supplier and the supplier has low attributes of power relative to the buyer (high/low), then the relationship is buyer dominance (>). Conversely, when the buyer has low power attributes relative to the supplier and the supplier has high power attributes relative to the buyer (low/high), then the relationship is supplier dominance $(<)$. When both the buyer and the supplier have high power attributes relative to each other (high/high), then the relationship is characterized by independence (0). Finally, when both the buyer and the supplier have low power attributes relative to each other (low/low), then the relationship is characterized by interdependence $(=)$. This is summarized in Figure 6.

These results are shown in Figure 7, with the questionnaire responses presented in Table 6 and 7 in the findings section of this paper. Authors go beyond the dyad to build up a picture of the power relationships and relationship management types within the supply chain.

The second step of data analysis was to position the relationships in one of the six possible relationship types shown in Figure 3. This was achieved by first determining the way of working. If the answer to question one in section A of the relationship management questionnaire is "yes", then the relationship is arms-length. All other relationships will be positioned in the matrix as close. However, to validate the "yes" answer and to provide further information about the degree of connectivity in the relationship, a further question is asked (question two in Section A of the "relationship management questionnaire"-Table 4). 


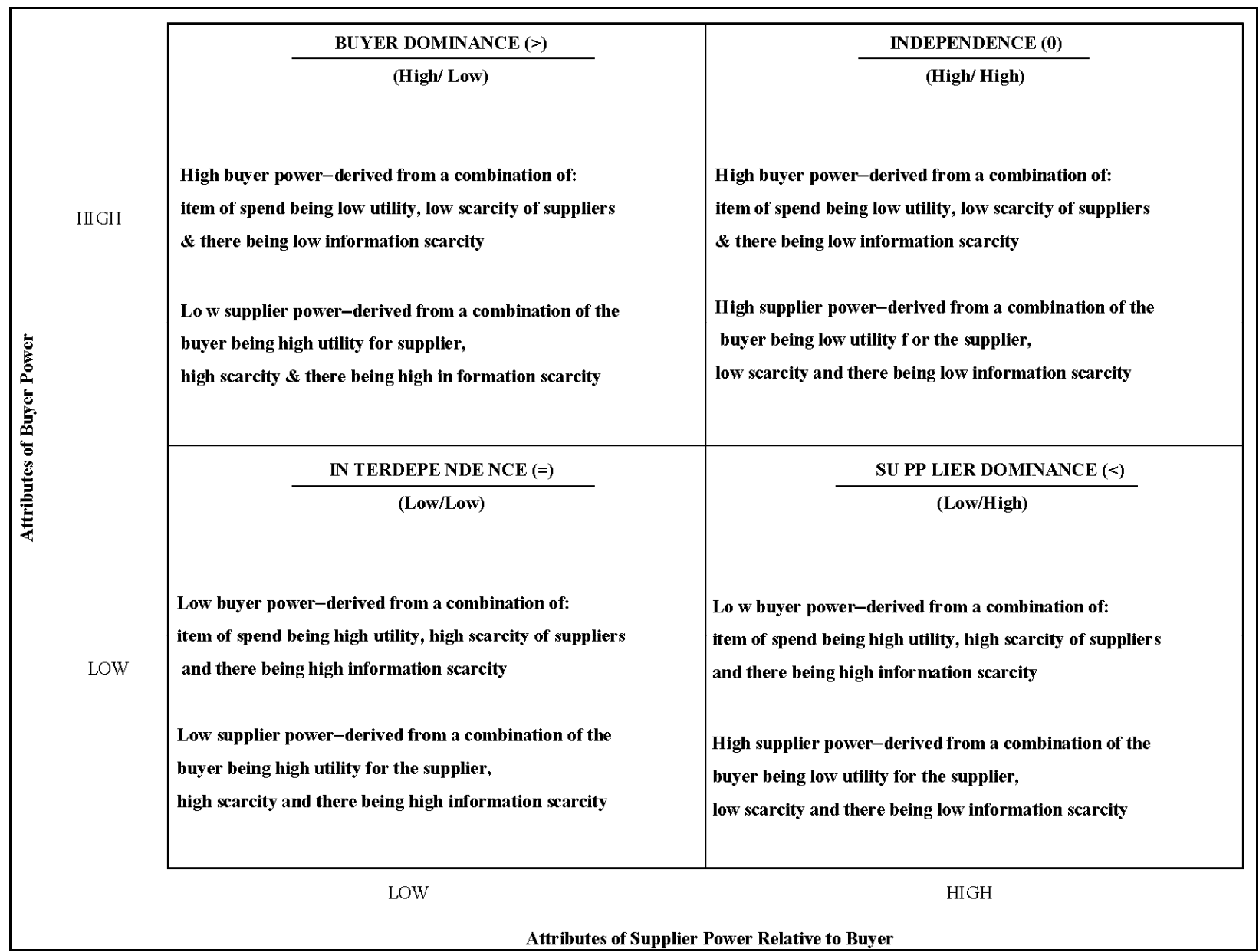

Figure 6. The power matrix: Bringing buyer and supplier power.

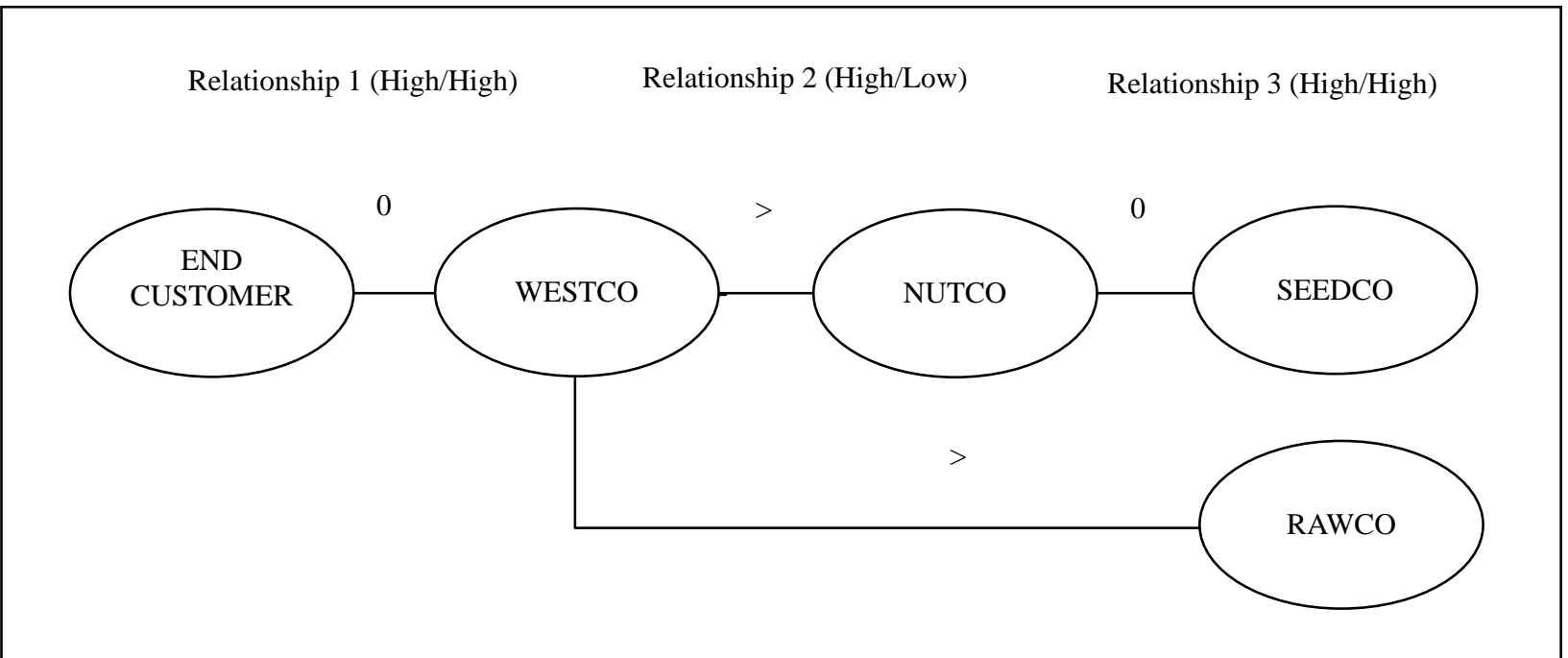

Figure 7. The power analysis for roasted seeds and nuts (Key to symbols: > = Buyer dominance, 0 = Independence for the full analysis see Table 6 and 7).

Secondly, six questions were asked in section B of the "relationship management questionnaire” to determine the sharing of surplus value in the relationship. Table 5 shows the characteristics of equal and 
unequal sharing of surplus value. The characteristics depicted in Table 5 aid the researcher when analyzing whether the surplus value created in the relationship is shared equally or favors either the buyer or supplier. Here, a judgment needs to be made as to who, on balance, gains more of the surplus value from the relationship. If it favors the supplier, for example, then the relationship will be deemed to be supplier-skewed adversarial. If it is very difficult to determine any obvious beneficiary, then the relationship will be classified as non-adversarial. These relationships will be discussed in more detail below.

\section{Findings}

Authors now examine the power relationships in the extended supply chain and the relationship management approach between Westco and Nutco. The dyadic power relationships in this chain are depicted in Figure 7, with the analysis provided in Table 6 and 7.

\section{End Customer-Westco Power Relationship (Relationship 1)}

The Shanghai store of Westco is typical of other large format multiple retail markets in the region. It has been successful in establishing itself in a new market and enjoyed an $18 \%$ market share in the region. The store services a large number of individual consumers, all of whom are able to switch relatively easily to alternative suppliers if they wished. "Although we have been successful, we are under no illusions that our customers can quite easily move to another similar competitor. We try and compete on price, but the quality of our produce is of great importance", said a marketing manager of Westco.

The power relationship between the end customer and Westco (Figure 7) has been analyzed as independence (0) (Table 6 and 7).

\section{Westco-Nutco Power Relationship (Relationship 2)}

Authors next examine the key relationship with Nutco. Westco purchased $60 \%$ of its goods from local suppliers, with non-branded roasted seeds and nuts single sourced over the previous two years from Nutco. The orders from Westco accounted for $80 \%$ of Nutco's revenue. There were a number of larger non-branded roasted seeds and nuts producers operating in Shanghai, but the shelf life of their products was reported to be at least $20 \%$ shorter than those of Nutco. The distinctive taste and aroma of Nutco's roasted products helped them to increase their market share and contributed 4\% to Westco's overall turnover. This provided important operational and commercial benefits. "Nutco's products are undoubtedly market leaders and nut products are an important category for us”, said a category buyer of Westco.

Westco achieved 25\% gross profit from sales and a 5\% lower price than it purchased from other suppliers. Despite this, the buyer demonstrated little understanding of the supplier's own cost and profit drivers in the relationship. Nutco was heavily dependent upon Westco for the majority of its business revenue. "For us, Westco is our most important customer by far; without them, it is unlikely that we could sustain the business", said an owner of Nutco.

Not only was $80 \%$ of its revenue generated from this relationship, but it also made such a low return that it had insufficient funds to purchase vehicles to distribute its products to other customers. Furthermore, this stopped it from providing a timely or reliable service for Westco. These factors enabled Westco to establish buyer dominance $(>)$ over Nutco. This is because Nutco provided high quality products, for normal returns (2\% net profit) and transparently passed all cost improvements to the buyer in return for regular work and low, but guaranteed margins (Table 6 and 7). 
Table 6

Analysis of Buyer Power Resources

\begin{tabular}{|c|c|c|c|c|c|}
\hline Interview Questions: & $\begin{array}{l}\text { High } \\
\text { power for } \\
\text { the buyer }\end{array}$ & $\begin{array}{c}\text { R 1: EC - } \\
\text { Westco }\end{array}$ & $\begin{array}{c}\text { R 2: } \\
\text { Westco - } \\
\text { Nutco }\end{array}$ & $\begin{array}{l}\text { R 3: Nutco } \\
\text { - Seedco }\end{array}$ & $\begin{array}{c}\text { R 4: } \\
\text { Westco - } \\
\text { Rawco }\end{array}$ \\
\hline 1. How operationally im portant is the item to be sourced? (U) & Low & Low & Medium & High & Low \\
\hline 2.Is the item sourced of comm ercial im portance? (U) & $\begin{array}{l}\text { Low (support } \\
\text { good) }\end{array}$ & Low & Medium & High & Low \\
\hline 3. What $\%$ of the total buyers spend is devoted to this item? (U) & Low & Low & Low & High & Low \\
\hline 4. Is reciprocity a factor in the relationship between the buyer and supplier? (U) & No & No & No & No & No \\
\hline 5. How m any potential suppliers are there for this item of spend? (S) & Many & Many & Restricted & Many & Many \\
\hline 6. How contested is the current supply $m$ arket? (S) & High & $\mathrm{High}$ & High & High & High \\
\hline 7. How com moditised is the supply offering (level of complexity)? (S) & Highly & Highly & Medium & Highly & Highly \\
\hline 8. Are credible substitute item s easily available?(S) & Yes & No & No & No & No \\
\hline 9. How high are the barriers to entry for new suppliers? (S) & Low & Low & Low & Low & Low \\
\hline $\begin{array}{l}\text { 10. How m any isolating m echanism s does the supplier have against their } \\
\text { competitors? (S) }\end{array}$ & None or Few & Few & Few & None & None \\
\hline 11. Does the buyer pose a realistic threat of backward integration? (S) & High & Low & Low & Low & Low \\
\hline 12.Is it possible to take the first-tier supplier out of the chain? (S) & High & Low & Low & Low & Low \\
\hline 13. What is the current evidence of cartelisation in this supply m arket? (S) & Low & Low & Low & Low & Low \\
\hline 14. What is the current level of lock-in by the supplier of the buyer's business? ( $\mathrm{S}$ ) & Low & Low & Low & Low & Low \\
\hline 15. How high are the buyer's switching costs? (S) & Low & Low & Low & Low & Low \\
\hline 16. Are the buyers search costs high or low? (I) & Low & Low & Low & Low & Low \\
\hline 17. Does the buyer have low or high levels of inform ation asym m etry? (I) & Low & Low & Low & Low & Low \\
\hline $\begin{array}{l}\text { 18. What type of product/service is being purchased(experience, search or } \\
\text { credence)? (I) }\end{array}$ & SearchGood & SearchGood & SearchGood & SearchGood & SearchGood \\
\hline $\begin{array}{l}\text { From the answers to these questions what is the overall assessm ent of the buyers } \\
\text { power resource endowm ents? }\end{array}$ & & $\begin{array}{l}\text { High Buyer } \\
\text { Power }\end{array}$ & $\begin{array}{l}\text { High Buyer } \\
\text { Power }\end{array}$ & $\begin{array}{l}\text { High Buyer } \\
\text { Power }\end{array}$ & $\begin{array}{l}\text { High Buyer } \\
\text { Power }\end{array}$ \\
\hline
\end{tabular}

\section{Nutco-Seedo Power Relationship (Relationship 3)}

Nutco was also supplied by a local Shanghai based raw seeds and nuts supplier-Seedco. The relationship between Nutco and Seedco was characterized as independence (0). This is because Seedco was one of several raw seeds and nut suppliers in the area. "There are many suppliers who can provide us with raw seeds and nuts. As these products are a commodity item we feel that it would be straightforward to move to an alternative supplier. There is little risk in doing so", said a buyer of Nutco.

It was relatively easy for Nutco to re-source this commodity from an alternative supplier. Equally Nutco was a relatively small client for Seedco, accounting for less than $1 \%$ of their turnover. In addition, there were many alternative buyers from different sectors, such as food manufacturers, requiring nuts as a raw material (Table 6 and 7). "We have over 100 clients for our product and although Nutco does buy regularly, it would be relatively easy to replace this customer”, said a marketing manager of Seedco.

\section{Westco-Rawco Power Relationship (Relationship 4)}

Westco was also able to establish buyer dominance (>) over Rawco, another supplier of non-roasted raw seeds and nuts (Figure 7). This was because Westco is a key client for Rawco, accounting for a significant proportion of their turnover, with the company not having a diverse client base. Whereas, these products only 
contributed 2\% towards Westco's total sales and this commodity could be relatively easily resourced from alternative suppliers (Table 6 and 7).

Table 7

Analysis of Supplier Power Resources

\begin{tabular}{|c|c|c|c|c|c|}
\hline Interview Questions: & $\begin{array}{l}\text { High power } \\
\text { for the } \\
\text { supplier }\end{array}$ & $\begin{array}{l}\text { R 1: EC - } \\
\text { Westco }\end{array}$ & $\begin{array}{l}\text { R 2: Westco } \\
\text { - Nutco }\end{array}$ & $\begin{array}{l}\text { R 3: Nutco- } \\
\text { Seedco }\end{array}$ & $\begin{array}{l}\text { R 4: Wesco- } \\
\text { Rawco }\end{array}$ \\
\hline $\begin{array}{l}\text { 1. How significant is the buyer's spend to the } \\
\text { operational sustainability of the supplier's business (i.e. } \\
\text { ratio, regular and predictable)? (U) }\end{array}$ & Low & Low & High & Low & High \\
\hline $\begin{array}{l}\text { 2. How com m ercially im portant is the buyer to the } \\
\text { supplier? (U) }\end{array}$ & Low & Low & High & Low & High \\
\hline $\begin{array}{l}\text { 3. Does the buyer provide supplier with clear and } \\
\text { consistent dem and forecasting and capacity planning } \\
\text { inform ation? (U) }\end{array}$ & Yes & No & Yes & Yes & Yes \\
\hline 4. Is the buyer's business attractive for the supplier? (II) & Low & Low & High & Low & High \\
\hline $\begin{array}{l}\text { 5. How th any custom ersin total does the supplier have } \\
\text { for this for this item? (S) }\end{array}$ & Many & Many & Few & Many & Few \\
\hline $\begin{array}{l}\text { 6. How m any potential custom ers are there for this } \\
\text { supplier? (S) }\end{array}$ & Many & Many & $\mathrm{Few}$ & Many & Few \\
\hline 7. How high are the suppliers sunk costs? (S) & Low & Low & High & Low & High \\
\hline $\begin{array}{l}\text { 8. Does the supplier have the ability to forward } \\
\text { integrate?(S) }\end{array}$ & Yes & No & No & Yes & No \\
\hline $\begin{array}{l}\text { 9. Does the supplier have access to private buyer } \\
\text { inform ation(i.e. budgets, reservation price, what is } \\
\text { valued, who specifies etc.)? (I) }\end{array}$ & Yes & No & No & No & No \\
\hline $\begin{array}{l}\text { From the answers to these questions what is the overall } \\
\text { a ssessm ent of the suppliers power resource } \\
\text { endowm ents? }\end{array}$ & & $\begin{array}{l}\text { High Supp lier } \\
\quad \text { Power }\end{array}$ & $\begin{array}{l}\text { Low Supplier } \\
\quad \text { Power }\end{array}$ & $\begin{array}{l}\text { High Supplier } \\
\text { Power }\end{array}$ & $\begin{array}{l}\text { Low Supp lier } \\
\text { Power }\end{array}$ \\
\hline
\end{tabular}

\section{Relationship Management Approach Between Westco and Nutco}

Westco was fully aware of the strong position they had in the market place. In this context, Westco chose to leverage their buyer dominant position to manage the relationship with Nutco in an arms-length and commercially adversarial manner (Figure 3). The buyer was able to appropriate the greater share of the value in the relationship. Westco chose to manage the relationship in an arms-length manner. It can be argued that this is an appropriate relationship management approach under the specific exchange circumstances. Although the purchase was not a one-off purchase, the products being offered by Nutco were commodity items requiring only a basic exchange of information (order quantities etc.) and products. Furthermore, although Nutco's products contributed towards overall revenue for Westco, they were by no means critical products in terms of their contribution to revenue and return. In addition, Westco was more used to managing similar suppliers outside of China in an arms-length way. "Our suppliers know that we are in a strong position and expect tough negotiations. We don't want to waste time and money getting too close to our suppliers; this would make our negotiations less affective”, said a category manager of Westco. 
Management felt that getting too close to their supplier was detrimental to achieve the most advantageous commercial outcome as relationships get in the way of sound commercial judgment. It can be argued, therefore, that the buyer achieves a win outcome from the exchange, but the supplier receives only a partial win. Westco achieves above normal returns and captures the major part of the commercial value created. Despite this, Nutco received regular high volumes and revenue but with only a very small return. This is initially, therefore, a nonzero-sum (win-partial win) outcome, because both parties benefited from the exchange (Figure 8: Cell B).
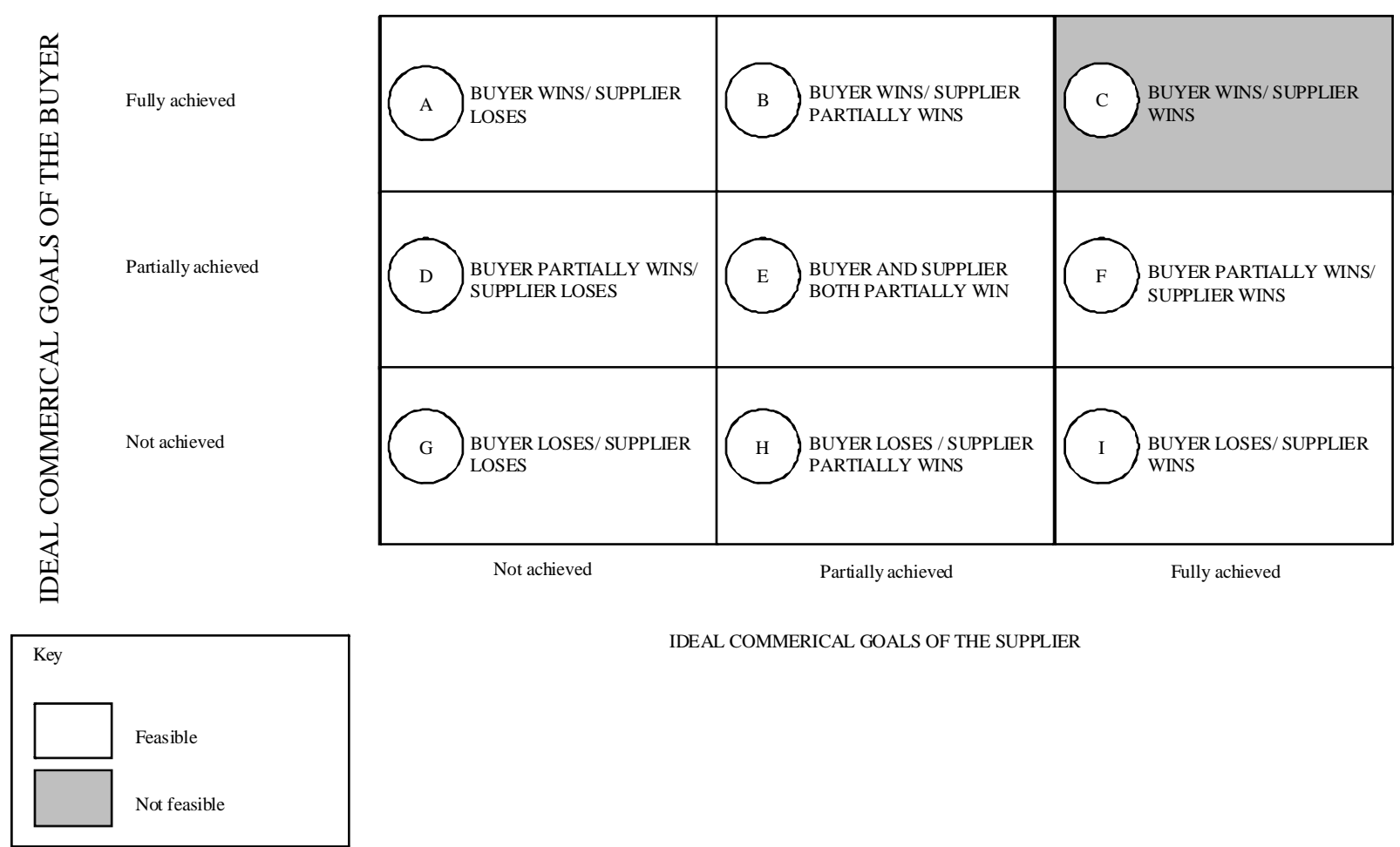

IDEAL COMMERICAL GOALS OF THE SUPPLIER

Figure 8. Commercial outcomes from buyer and supplier exchange. Source: Cox (2004, p. 25).

\section{Relationship Breakdown}

Over time Westco suffered poor cash flow because of its rapid market expansion program and its market share declined due to the arrival in Shanghai of another major international multiple food retailer. "We enjoyed a period of growth, whilst we were one of the only international multiple food retailers in Shanghai. However, with greater competition, market share is lost. All aurhors can do is to try and cut costs and become more competitive. However, this is not easy to achieve in China, as our local suppliers seem unwilling to cut costs themselves", said a general manager of Westco.

To improve its short-term financial performance and to reduce purchasing costs, Westco, following the adversarial logic it had learnt in the west, unilaterally demanded that Nutco accepts longer payment terms and provides further price discounts. Given the prevailing objective power position, Nutco initially has no option but to accept the revised terms and conditions imposed upon them. This is principally because, in the short-term, Nutco could not afford to purchase vehicles to market and deliver its products to other potential retail customers, and there was an inadequate legal framework to protect its original contractual terms (Allen, Qian, \& Qian, 2005). 
The result of this more adversarial arms-length positioning by Westco was that the relationship moved from nonzero-sum favoring the buyer (Cell B in Figure 8) to a zero-sum (win-lose) outcome favoring the buyer (Cell A). Under the new terms and conditions imposed by Westco, it was impossible for Nutco to make any profit, and it soon suffered financial difficulties. In order to stay in business, Nutco acted opportunistically and, without informing the buyer, reduced the quality of its products by using inferior raw materials, as well as the safety and hygienic control budget. To reduce transaction costs, Westco does not have sufficiently robust internal quality control processes and it does not check the quality of Nutco's products. "We rely upon our suppliers to ensure that our high quality standards are maintained. This is common practice in our other non-Chinese stores. The fear of losing our business ensures that our suppliers delivered what we want and always on time”, said a general manager of Westco.

Inadvertently Westco sold inferior quality roasted seeds and nuts to consumers. In this way, Nutco attempted, unilaterally, to move the relationship back to the non-zero-sum (buyer win-supplier partial win) outcome depicted in Cell B in Figure 8.

The result was that, two months later, 13 people were reported to have suffered health issues from eating Westco's inferior roasted seeds and nuts products. Nutco was fined and soon afterwards went bankrupt and Westco suffered a serious reputational embarrassment and heavy financial losses due to a rapid decline in sales and market share. The consequence of this exchange is that both parties end up in a negative-sum (or lose-lose) outcome, as depicted in Cell G in Figure 8.

\section{Discussion and Analysis}

As highlighted in the case, from a power and leverage perspective, Westco could have managed their relationship with Nutco in a number of ways (Figure 3). The first choice for Westco was whether to have an arms-length or collaborative relationship with Nutco. In this case, the decision to manage the relationship in an arms-length manner was influenced by the nature of the product being purchased and the cultural predisposition of the buying organization. It would seem that more proactive collaboration was never on the agenda. A Westco category buyer stated that, "These products (nuts) were commodity items; we just didn't feel that the relationship warranted taking the time to understand the supplier better. I still think that we managed the relationship in the right way”.

The second choice for Westco was how to share the surplus value in the relationship. As the power and leverage perspective emphasizes, regardless of whether the relationship is managed in an arms-length or collaborative manner, the benefits can broadly speaking be shared equally (balanced or non-adversarial) or unequally (unbalanced or adversarial). The case indicated that the highly adversarial commercial practices that Westco has historically developed in the west; leveraging their buyer dominant position aggressively to suit their own strategic short-term goals, without thought for the consequences for their suppliers, elicited a very different response to that which they were used to. Normally, dominant buyers in the west can assume that their suppliers will either accept the newly imposed terms of the deal or they will walk away from it. According to a general manager of Westco, "We were in, what we believed to be such a strong position that we never envisaged our nut supplier doing anything other than complying with our demands".

Those accepting the aggressive adversarial stance of the buyer are normally suppliers who have few other options, who will accept the short-term leverage of the buyer in the hope of maintaining the relationship and negotiating an improved deal later. Previous research indicates that UK-based multiple retailers effectively use 
their dominant power position to continuously re-negotiate better terms over their suppliers in many categories (Cox \& Chicksand, 2008). Those walking away are likely to be companies that have alternative options, or who have decided that working for nothing is not an acceptable commercial position to be in and who would rather exit and try their luck elsewhere.

What Westco did not bargain for, and this presumably explains why they did not create a robust quality control system to check incoming products, was that their own short-term opportunism would be repaid back to them in full by one of their suppliers. Possible reasons for this include that Westco did not fully understand the immaturity of the business environment or the Chinese cultural norms, when a supposed "partner" behaves opportunistically against the other "partner", and even when the relationship is one of master-servant (or buyer dominance).

There are a number of important management and theoretical lessons which can be drawn from this analysis. This paper will address the theoretical implications first.

\section{Theoretical Implications}

It has been argued that, in the western context, from a power and leverage perspective, it is appropriate to manage relationships in either an arms-length or collaborative way. Western organizations adopting a portfolio approach to relationship management are, some would say, demonstrating best practice (Olsen \& Ellram, 1997). However, in the Chinese business context where equity and trust are highly regarded principals, a relational approach for investigating the phenomenon of buyer-supplier exchanges seems to be a more natural fit than the power and leverage perspective. The analysis suggests that the arms-length categorizations shown in Figure 3 are unlikely to be applicable in the Chinese context. Arms-length relationships in this context could produce sub-optimal outcomes for both buyers and suppliers. This suggests that "relationship management choice matrix" requires adaptation in the Chinese context.

Authors argue that a relational approach is inadequate for fully explaining the dynamics of buyer-supplier exchanges in the Chinese cultural context. This is because to understand business relationships, a distinction must be made between the way of working and the sharing of value and risks. Relational theory helps to recognize the appropriate way of working for business relationship in the Chinese context. However, this approach is inadequate for explaining how value and risk are shared in business relationships. The explanation for this is that the relational approach does not acknowledge that power can shape the outcome of a buyer-supplier exchange. Writers from the power and leverage perspective as well as the broader RDT perspective, have long argued that the power between buyers and suppliers largely dictates how value and risk, even in highly collaborative relationships, are ultimately shared. The relational approach literature assumes that collaboration will lead to a balanced sharing of risk and rewards. In the western business context, this assertion is difficult to justify. One only has to consider the collaborative "partnership" relationships between the dominant UK multiple food retailers and many of their suppliers to see this (Cox \& Chicksand, 2005, 2008; Tallontire \& Vorley, 2005; Competition Commission, 2000, 2008). Furthermore, in the Chinese context, the underlying power relationships also help shape the sharing of surplus value in buyer-supplier relationships. That is to say that the central principals of the power and leverage perspective are still applicable for understanding business relationships in the Chinese context. However, the expression of this power position is much more subtle than in the western context. It is suggested that the dominant party in buyer-supplier relationships in China will still gain an unequal proportion of the benefits from the relationship. However, the 
distribution of the gains and risks will be negotiated more collegially.

If this paper returns to earlier discussion of power, it can be seen that there is indeed a need for further research on both the boundary conditions for the power and leverage perspective and for more cross-national studies using this perspective beyond the western context. The research suggests that it may not be appropriate to make any unilateral resolution in negotiations before communicating with business partners collaboratively. If the powerful party in an exchange appears to take too much commercial advantage of the other party, its business partner will then also become adversarial in return and "fights back with viciousness" (a popular Chinese proverb). "Win-lose” or zero-sum outcomes, based on aggressive buyer or supplier behavior are, therefore, highly unsustainable in the Chinese business context. In this way, it can be argued that the face of power most relevant to the Chinese context may be either power as manipulation or domination (Fleming \& Spicer, 2006).

It can be argued that in the Chinese context using power as coercion is an extremely counterproductive relationship management strategy — which will draw both parties into a "no-win" or negative sum situation. This is a dangerous proposition within the current Chinese business environment, where property rights and contract law are virtually nonexistent (Graham \& Lam, 2003; Allen et al., 2005).

What this suggests, therefore, is that the continuum of who appropriates value from the relationship still exists (as shown in Figure 3), but it is less likely even if there are significant power differentials between the buyer and supplier that will be fully commercially exploited. The dominant party will more likely be willing to forgo some of their power (and the ability to retain more surplus value) in favor of creating an atmosphere of long-term harmony. This supports the notion identified by French and Raven (1959) that an actor within a relationship with potential power may at times choose not to exert it. This paper would also suggest that in the Chinese context, out of the nine theoretical commercial outcomes identified by Cox (2004), and shown in Figure 8, the most likely outcomes are B, E, and F. Cox (2004) argued that position C is not feasible, as it is never possible for both buyers and suppliers to fully achieve their commercial goals. It is possible, however, that in the Chinese context this may not be accurate. The analysis therefore supports P1: In a Chinese business context due to the influence of Guanxi and Mianzi, it is unlikely that power differentials in a relationship will be exploited.

Developing on from proposition 1, it proposes a second proposition: P2: In the Chinese cultural context, both adversarial and arms-length relationship management approaches will result in sub-optimal commercial outcomes.

\section{Management Implications}

What this case indicates is that Westco did not understand that having significant structural power resources over their supplier may not be a guarantee in China that they would be able to aggressively leverage lower prices, whilst maintain quality and delivery standards. In this context, having a contract was meaningless. Regardless of the strong power position of the buyer, without a harmonious relationship with the supplier there is, in practice, no guarantee that the terms and conditions specified in the contract will be delivered. This phenomenon is the result of traditional business customs in China, and also because the law at present inadequately protects the terms of a contract (Allen et al., 2005).

There are two interrelated management learning points to be derived from the case. Firstly, in the Chinese business context it may not be advisable to manage any relationship in an arms-length manner. Keister (2001) 
argued that the selection of exchange partners in China is driven by their reputation. Knowing a supplier in advance is crucial for relationships success as this reduces uncertainty. To overcome the complexity and risk associated with trading in China, it is wise to avoid arms-length transactions and secure trustworthy partners who have secure access to scarce resources, even if it is possible to find cheaper alternatives. This contradicts "market theorist who believe actors prefer to trade across a market" (Keister, 2001). Chinese business culture tends to revere long-term collaborative relationships with partners. Furthermore, arms-length relationships are impolite and unpopular in buyer and supplier exchanges. This is because of the existence of inseparable interpersonal relationships between buyers and suppliers—commonly called "Guanxi"-which is based on social and family networks (Li et al., 2001; Graham \& Lam, 2003; Vanhonacker, 2004). As a result, mutually beneficial non-zero-sum forms of collaboration are the key to establishing harmonious relationships in Chinese business activities.

Secondly, organizations operating in China, even in long-term collaborative relationships should be wary of explicitly exploiting their position of power. That is not to say that power dynamics are not at play in business relationships in China. On the contrary, power relationships are at the heart of doing business there. Business leaders in China develop power by creating dependency (Keister, 2001) and according to Hofstede (2007) power is one of the five most important perceived goals ascribed to business leaders in China. In addition, to successfully conduct business in China, it is important to have prior connections, market position, and bureaucratic power to develop alliances (Keister, 2001).

In the western context, it can be argued that coercive power is the predominant face of power when talking about buyer-supplier relationships. However, in the Chinese business culture, power seems to be exercised in a different way. Chinese business networks are centred on less explicit or formal power relationships. Instead, they are based upon dominant or lead organizations with paternalistic connection with other organizations. In this way, it can be argued that the face of power most relevant to the Chinese context may be either power as manipulation or domination (Fleming \& Spicer, 2006).

In conclusion, the case illustrates that relationship management choices are influenced by the specific cultural context of the buyer-supplier relationship. Companies that have learnt the rules of the game of exchange in the west will have to modify their approach, when they enter a market in which the rule of law is less formalized than it is in their traditional markets and supply chains (Graham \& Lam, 2003). It would appear that the structural power resources of buyers may be severely affected by opportunism if the legal framework does not protect the rights of buyers or suppliers contractually (Allen et al., 2005). This may imply that in such an environment buyers may have to eschew short-term commercially aggressive adversarial leverage in favor of non-adversarial approaches. Furthermore, a collaborative rather than an arms-length way of working is likely to be more appropriate, even if it comes at a cost.

\section{Conclusions}

The key research question introduced at the beginning of this paper was:

RQ: Does the power and leverage perspective need modifying in non-western contexts?

The research presented in this paper suggests that the power and leverage perspective is applicable for investigating buyer-supplier relationships in a Chinese cultural context. However, this paper has also highlighted some potential boundary conditions of a power and leverage perspective by exploring 
buyer-supplier relationships in the Chinese business context.

This paper developed one theory-based proposition and a further empirically based proposition. These were:

P1: In a Chinese business context due to the influence of Guanxi and Mianzi it is unlikely that power differentials in a relationship will be exploited.

P2: In the Chinese cultural context both adversarial and arm's-length relationship management approaches will result in sub-optimal commercial outcomes.

The findings presented within this paper support both of these propositions. However, a limitation of this study is that the findings were based upon a single case. This makes it difficult to draw general sable conclusions. Therefore, additional research in the Chinese business context is required to validate the two propositions presented in this paper. There is further limitation of this study. Analyzing buyer-supplier power relationships and relationship management types is complicated. The researcher must gather detailed, often commercially sensitive information, from both buying and supplying organizations. Every attempt was made to limit the subjectivity of the subsequent analysis through the adoption of a clearly structured data collection and analysis process. However, positioning relationships in the power matrix and the relationship management type matrix require a degree of interpretation of data by the researcher.

There is considerable scope for additional future research. It would be interesting to apply a perspective to studying buyer-supplier relationships in other cultural context, for example, the Middle East or Africa (see Wouters, van Jarwaarde, \& Groen, 2007). Furthermore, there is still much work yet to be done in applying and when necessary adapting the power and leverage perspective for helping researchers understand phenomenon such as buyer-supplier relationships within and outside the western business context.

This paper has attempted to make a number of theoretical contributions. In addition, the research has suggested a number of potentially important managerial implications. The Chinese market offers many exciting opportunities for western companies. However, companies like price-mart have discovered that business success in China is not guaranteed ${ }^{2}$ (China Operational Management, 2004). The case study presented in this paper suggests that given the current state of economic and social development in China a collaborative approach may well be superior to traditional western arms-length approaches. In addition, in increasingly difficult economic times, it can be argued that for organizations in the west it may be more prudent to cease short-term profit maximizing actions, in favor of taking a long-term, more collaborative approach to relationship management.

\section{References}

Allen, F., Qian, J., \& Qian, M. (2005). Law, finance, and economic growth in China. Journal of Financial Economics, 77, 57-70.

Bachrach, P., \& Baratz, M. S. (1962). Two faces of power. The American Political Science Review, 56(4), 947-952.

Blau, M. (1964). Exchange and power in social life. New York: Wiley.

Boisot, M. (1986). Markets and hierarchies in a cultural perspective. Organization Studies, 7(2), 135-158.

Boisot, M., \& Child, J. (1996). From fiefs to clans and network capitalism: Explaining China's emerging economic order. Administrative Science Quarterly, 41, 600-628.

Bowles, S., \& Gintis, H. (1993). The revenge of homo economicus: Contested exchange and the revival of political economy. The Journal of Economic Perspective, 7(1), 83-102.

\footnotetext{
${ }^{2}$ When the Chinese business of this US-based multiple food retailer failed after an eight-year struggle, a manager was reported as saying: "It is painful, especially when you don’t understand their ways of doing business".
} 
Cai, S., Yang, Z., \& Hu, Z. (2010). The effects of volume consolidation on buyer-supplier relationships: A study of Chinese firms. Journal of Purchasing and Supply Management, 16(3), 152-162.

Cambra-Fierro, J., \& Ruiz-Benitez, R. (2011). Notions for the successful management of the supply chain: Learning with carrefour in Spain and carrefour in China. Supply Chain Management: An International Journal, 16(2), 148-154.

Campbell, N. C. G., \& Cunningham, M. T. (1983). Customer analysis for strategy development in industrial markets. Strategic Management Journal, 1, 360-380.

Caniëls, M., \& Gelderman, C. (2005). Purchasing strategies in the Kraljic matrix-A power and dependence perspective. Journal of Purchasing and Supply Management, 11(2-3), 141-155.

Cannon, J., \& Perrault, W. (1999). Buyer-seller relationships in business markets. Journal of Marketing Research, 32, 430-460.

Chen, A., \& Vishwanath, V. (2005). Expanding in China. Harvard Business Review, 83(3), 19-21.

China Operational Management. (2004). Price-mart's Chinese dream end up with bankrupt after eight years' struggling (China Operational Management, 27th December, Beijing, China).

Choi, T. Y., \& Wu, Z. (2009). Triads in supply networks: Theorizing buyer-supplier-supplier relationships. Journal of Supply Chain Management, 45(1), 8-25.

Competition Commission. (2000). Supermarkets: A report on the supply of groceries for multiple retailer stores in the UK, London: Competition Commission.

Competition Commission. (2008). The supply of groceries in the UK: Market investigation. London: Competition Commission.

Contu, A., \& Willmott, H. (2003). Re-embedding situatedness: The importance of power relations in learning theory. Organization Science, 14(3), 283-296.

Cook, K. S. (1977). Exchanges and power in networks of inter-organizational relations. Sociology Quarterly, 18, 62-82.

Cook, K. S., \& Emerson, R. M. (1978). Power, equity, and commitment in exchange networks. American Sociology Review, 43, 721-739.

Cox, A. (2004). Win-win? The paradox of value and interests in business relationships. Stratford-upon-Avon: Earlsgate Press.

Cox, A. (2007). Transactions, power and contested exchange: towards a theory of exchange in business relationships. International Journal of Procurement Management, 1(1-2), 38-59.

Cox, A., \& Chicksand, D. (2005). The limits of lean management thinking: Multiple retailers and food and farming supply chains. European Management Journal, 23(6), 648-662.

Cox, A., \& Chicksand, D. (2008). Rethinking policy options for industry: Appropriateness in policies for industry and for UK farming and food. Public Administration, 86(30), 823-836.

Cox, A., Sanderson, J., \& Watson, G. (2000). Power regimes: Mapping the DNA of business and supply chain relationships. Stratford-upon-Avon: Earlsgate Press.

Cox, A., Ireland, P., Lonsdale, C., Sanderson, J., \& Watson, G. (2002). Supply chains, markets and power: Mapping buyer and supplier power regimes. London: Routledge.

Cox, A., Ireland, P., Lonsdale, C., \& Sanderson, J. (2003). Supply chain management: A guide to best practice. London: Prentice Hall.

Cox, A., Lonsdale, C., Sanderson, J., \& Watson, G. (2004). Business relationships for competitive advantage: Managing alignment and misalignment in buyer and supplier transactions. Basingstoke: Palgrave Macmillan.

Dahl, R. A. (1957). The concept of power. Behavioral Science, 2(3), 201-215.

Dyer, J. H., \& Singh, H. (1998). The relational view: Cooperative strategy and sources of interorganizational competitive advantage. Academy of Management Review, 23(4), 660-679.

Dyer, J. H. (1996). Specialized supplier networks as a source of competitive advantage: Evidence from the auto industry. Strategic Management Journal, 17(4), 271-271.

Eisenhardt, K. M. (1989). Agency theory: An assessment and review. The Academy of Management Review, 14(1), 57-74.

El-Ansary, A. L., \& Stern, L. W. (1972). Power measurement in the distribution channel. Journal of Marketing Research, 9(1), 47-52.

Emerson, R. M. (1962). Power-dependence relations. American Sociology Review, 27, 31-41.

Emberson, C., \& Storey, J. (2006). Buyer-supplier collaborative relationships: Beyond the normative accounts. Journal of Purchasing and Supply Management, 12(5), 236-245.

Fleming, P., \& Spicer, A. (2006). Contesting the corporation: Struggle, power, and resistance in organizations. Cambridge: Cambridge University Press. 
Fontenot, R. J., \& Wilson, E. J. (1997). Relational Exchange: A review of selected models for a prediction matrix of relational activities. Journal of Business Research, 39(1), 5-12.

Foucault, M. (1982). The subject and power. Critical Inquiry, 8(4), 777-795.

French, J. R. P., \& Raven, B. (1959). The bases of social power. In D. Cartwright (Ed.), Studies in social power (pp. 259-269). Ann Arbor: Institute for social research.

Gadde, L., \& Snehota, I. (2000). Making the most of supplier relationships. Industrial Marketing Management, 29(4), $305-316$.

Gallie, W. B. (1955). Essentially contested concepts. Proceedings of the Aristotelian Society, 56, 170-171.

Graham, J., \& Lam, N. (2003). The Chinese negotiation. Harvard Business Review, 81(10), 82-91.

Hillman, A. J., Withers, M. C., \& Collins, B. J. (2009). Resource dependence theory: A review. Journal of Management, 35(6), 1404-1427.

Himmelweit, S., Simonetti, R., \& Trigg, A. (2001). Microeconomics: Neoclassical and institutionalist perspectives on economic behaviour. London: Thomson Learning.

Hofstede, G. (1980). Culture's consequences: International differences in work-related values. Beverly Hills: Sage.

Hofstede, G. (2007). Asian management in the 21st century. Asia Pacific Journal of Management, 24, 411-420.

Hofstede, G., \& Hofstede, G. J. (2005). Cultures and organizations: Software of the mind (2nd ed.). New York: McGraw-Hill.

House, R., Javidan, M., \& Dorfman, P. (2001). Project globe: An introduction. Applied Psychology: An International Review, 50(4), 489-505.

Humphreys, P. K., Shiu, W. K., \& Chan, F. T. S. (2001). Collaborative buyer-supplier relationships in Hong Kong manufacturing firms. Supply Chain Management: An International Journal, 6(4), 152-162.

Ireland, R. D., Webb, J. W., \& Coombs, J. E. (2005). Theory and methodology in entrepreneurship research. In D. J. Ketchen, \& D. D. Bergh (Eds.), Research methodology in strategy and management (pp. 111-141). Bingley: Emerald Group Publishing Ltd.

Jacobs, J. (1974). Dependency and vulnerability: An exchange approach to the control of organizations. Administrative Science Quarterly, 19(1), 45-59.

Jap, S. D. (1999). Pie-expansion efforts: Collaboration processes in buyer supplier relationships. Journal of Marketing Research (JMR), 36(4), 461-475.

Jiang, B. (2002). How international firms are coping with supply chain issues in China. Supply Chain Management: An International Journal, 7(4), 184-188.

Keister, A. (2001). Exchange structures in transition: Lending and trading relations in Chinese business groups. American Sociological Review, 66(3), 336-360.

Kim, K. K., Park, S. H., Ryoo, S. Y., \& Park, S. K. (2010). Inter-organizational cooperation in buyer-supplier relationships: Both perspectives. Journal of Business Research, 63(8), 863-869.

Lave, J., \& Wenger, E. (1991). Situated learning: Legitimate peripheral participation (learning in doing: Social, cognitive and computational perspectives). Cambridge: Cambridge University Press.

Lee, S. H., \& Oh, K. (2007). Corruption in Asia: Pervasiveness and arbitrariness. Asia Pacific Journal of Management, 24(1), 97-114.

Leenders, M. R., \& Blenkhorn, D. L. (1988). Reverse marketing: The new buyer-supplier relationship. New York: The Free Press.

Leung, K., Kock, P. T., \& Lu, L. (2002). A dualistic model of harmony and its implications for conflict resolution in Asia. Asia Pacific Journal of Management, 19, 201-220.

Li, J., Lam, K., \& Qian, G. (2001). Does culture affect behaviour and performance of firms? The case of joint ventures in China. Journal of International Business Studies, 32(1), 115-131.

Lieberthal, K., \& Lieberthal, G. (2003). The great transition. Harvard Business Review, 81(10), 70-81.

Lonsdale, C. (2004). Player power: Capturing value in the English football supply network. Supply Chain Management: An International Journal, 9(5), 383- 391.

Lukes, S. (1974). Power: A radical view. London: Macmillan.

Luo, Y. (1997). Guanxi and performance of foreign-invested enterprises in China: An empirical inquiry. Management International Review (MIR), 37(1), 51-70.

Meehan, J., \& Wright, G. (2011). Power priorities: A buyer-seller comparison of areas of influence. Journal of Purchasing and Supply Management, 17(1), 32-41.

Mintzberg, H. (1983). Power in and around organizations. Englewood Cliffs: Prentice-Hall.

Oliver, C. (1990). Determinants of interorganizational relationships: Integration and future directions. Academy of Management Review, 15, 241-265. 
Olsen, R. F., \& Ellram, L. M. (1997). A portfolio approach to supplier relationships. Industrial Marketing Management, 26(2), 101-113.

Park, S. H., \& Luo, Y. (2001). Guanxi and organizational dynamics: Organizational networking in Chinese firms. Strategic Management Journal, 22, 455-477.

Pettigrew, A. M. (1977). Strategy formulation as a political process. International Studies of Management and Organization, 7(2), 78-87.

Pfeffer, J. (1981). Power in organizations. Marshfield: Pittman.

Pfeffer, J., \& Salancik, G. R. (1978). The external control of organizations: A resource dependency perspective. New York: Harper and Row.

Porter, M. E. (1980). Competitive strategy: Techniques for analyzing industries and competitors. New York: The Free Press.

Porter, M. E. (1979). How competitive forces shape strategy. Harvard Business Review, 57(2), 137-145.

Ramsay, J. (1996). The case against purchasing partnerships. International Journal of Purchasing and Materials Management, 32(3), 13-21.

Ribbink, D., \& Grim, C. (2010). The impact of cultural differences in contractual buyer-supplier relationships (Working paper for The Council of Supply Chain Management Professionals (CSCMP), 1-16).

Rumelt, R. P. (1987). Theory, strategy and entrepreneurship. In D. Teece (Ed.), The competitive challenge: Strategies for industrial innovation and renewal (pp. 137-158). New York: Harper and Row.

Salmi, A. (2006). Organising international supplier relations: An exploratory study of Western purchasing in China. Journal of Purchasing and Supply Management, 12(4), 197-208.

Spekman, R. (1988). Strategic supplier selection: Understanding long-term buyer relationships. Business Horizons, 31, 75-81.

Spekman, R. E., Forbes III, T. M., Isabella, L. A., \& MacAvoy, T. C. (1998). Alliance management: A review from the past and a look to the future. Journal of Management Studies, 35, 747-772.

Su, Q., Song, Y. T., Li, Z., \& Dang, J. Z. (2008). The impact of supply chain relationship quality on cooperative strategy. Journal of Purchasing and Supply Management, 14(4), 263-272.

Tallontire, A., \& Vorley, B. (2005). Achieving fairness in trading between supermarkets and their agrifood supply chains. London: Food Group.

Thompson, J. D. (1967). Organizations in action. New York: McGraw-Hill.

Ulaga, W., \& Eggert, A. (2006). Relationship value and relationship quality: Broadening the nomological network of business-to-business relationships. European Journal of Marketing, 40, 311-327.

Vanhonacker, W. (2004). When good Guanxi turns bad. Harvard Business Review, 82(4), 18-19.

Voss, C., Tsikriktsis, N., \& Frohlich, M. (2002). Case research in operations management. International Journal of Operations and Production Management, 22(2), 195-219.

Whitley, R. D. (1994). Dominant forms of economic organization in market economies. Organizational Studies, 15, $153-182$.

Williamson, O. E. (1985). The economic institutions of capitalism: Firms, markets, contracting. New York: The Free Press.

Williamson, O. E. (1995). Hierarchies, markets and power in the economy. Industrial and Corporate Change, 4(1), 21-49.

Williamson, O. E. (1975). Markets and hierarchies: Analysis and antitrust implications. New York: The Free Press.

Wouters, M., van Jarwaarde, E., \& Groen, B. (2007). Supplier development and cost management in Southeast Asia—Results from a field study. Journal of Purchasing and Supply Management, 13(4), 228-244.

Xin, K. R., \& Pearce, J. L. (1996). Guanxi: Connections as substitutes for formal institutional support. Academy of Management Journal, 39, 1641-1658.

Yang, M. M. (1994). Gifts, favors and banquets: The art of social relationships in China. Ithaca: Cornell University Press.

Yin, R. (1994). Case study research—Design and methods (2nd ed.). London: Sage.

Yin, R. (2003). Case study research—Design and methods (3rd ed.). London: Sage.

Zaheer, A., McEvily, B., \& Perrone, V. (1998). Does trust matter? Exploring the effects of interorganizational and interpersonal trust on performance. Organization Science, 9(2), 141-159. 